distinguished candidate is available, for research in any branch of chemistry, pure or applied, and no restrictions will be placed upon the manner in which the prize is utilised by the recipient. The donors of the fund, explained Sir George Beilby, hope that the prize will do something to stimulate young research chemists to greater effort, form a not unworthy tribute to the memory of Col. Harrison, and serve to remind the chemists of the future how their science was employed in the cause of right and humanity.

Sir James Walker, president of the Chemical Society, in a brief speech accepted the fund and trust deeds, and the custody of the permanent memorial. Before unveiling the latter, Earl Crawford referred with sympathetic insight to the work of Col. Harrison during the war, and to the loss suffered by the country in the death of Harrison and the remaining Fellows of the Society whose names are inscribed upon the memorial. He expressed the hope and belief that the prize fund would fulfil the desire of the donors to encourage the younger chemists in research, a purpose which Harrison had ever in his thoughts. The unveiling of the memorial was marked by the sounding of the "Last Post" ; after a minute's silence the "Reveille" concluded a simple and dignified ceremony.

The permanent memorial (Fig. I) is the work of Mr. Ernest Gillick; it is of singular beauty. The bronze medallion bears an appropriate representation of a trench scene at the moment of a gas alarm. It is set upon marble, the natural colour of which harmonises with the bronze. In the rooms of the Chemical Society the memorial finds a most fitting home, and it is satisfactory to know that, should the Society change its quarters, it will be possible to transfer the memorial to the new rooms. $\quad$ C. R. Y.

\title{
Long Distance Telephony.
}

M R. F. GILL, the "European Engineer-in-Chief" of telephony over long distances, with special reference to the international problems of communication between the various countries of Europe, in his presidential address to the Institution of Electrical Engineers delivered on November 2 . Incidentally he pointed out that the passive attitude of a Government, content to satisfy the public demand only, would never lead to an efficient service. The success of the "Bell-owned" companies in the United States is due to an intensive educational campaign coupled with construction well in advance of the demand. In the United States the number of telephone stations has been increased ninefold during the last twenty years, and there is now one telephone station to every 7.7 persons. In $\mathrm{Mr}$. Gill's opinion a Government Department should earn something more than merely sufficient to pay its way. If this were done there would be no difficulty in getting the capital necessary to extend the business. With a large staff it is disastrous that the idea should prevail that profit-earning is of no account.

Mr. Gill stated that the "carrier" system has greatly increased the maximum load possible on given lines. In this system carrier waves of frequency between 4000 and 27,000 per second are used, and by means of "wave filters" they can be separated into different circuits without difficulty.
On the New York-San Francisco line there are four conductors which form simultaneously two physical, one phantom, and four earthed telephone circuits. They also form part of a varying number of telegraph circuits ranging from six to twenty. The introduction of the thermionic repeater in $\mathrm{rgI}_{4}$ gave a great impetus to telephonic development. As many as 23 of these repeaters have been used in tandem without seriously distorting speech. Mr. Gill gave data to prove that the telephone system of the United States is in advance of European systems.

In conclusion Mr. Gill discussed the problem of improving the through telephonic system of Europe. In Europe there is no organisation to co-ordinate the forty local systems. If a line were constructed between London and Christiania it would probably traverse six intermediate countries. The direct distance between London and Bagdad is about the same as that between New York and San Francisco, between which daily conversations take place. Under present conditions through telephony in Europe can be of little value. Mr. Gill then suggested alternative schemes for international control and urged that every endeavour should be made to secure it. The telephone authorities of Europe should hold a conference to try to find a solution, for to be interested jointly in a flourishing telephone undertaking would increase goodwill among nations.

\section{Low Temperature Carbonisation. ${ }^{1}$}

\section{By Prof. Jонn W. Совв.}

THE report of the Fuel Research Board for the years I920-2I on " Low Temperature Carbonisation " has been awaited with interest in many quarters because the subject has been much debated, and it was known that experiments were being carried out by Sir George Beilby and his staff at the Greenwich experimental station. On one hand, the process has been spoken of in terms of unrestricted enthusiasm and optimism as providing a simple and general solution of the smoke problem through the smokeless solid fuel which was to be produced, and as yielding large supplies of liquid fuel for naval and other purposes through its promised high yields of tar. On the other hand, critics of the process have indicated some shortcomings. The gas yield is small, and the process of carbonisation as carried on at higher temperatures in the gasworks is paid for

1 Department of Scientific and Industrial Research. Report of the Fuel Research Board for the Years r920, r921. Second Section: Low TemperaResearch Board for the Years r 220 , 1921 . Second Section: Low Tempera-
ture Carbonisation. Pp. iv $+73+8$ plates. (London: H.M. Stationery ture Carbonisation.

No. 2769 , VOL. I IO] mainly by the large volume of gas which can carry a much higher price per thermal unit than a solid fuel because each thermal unit is worth so much more in use. Again, one of the principal by-products of carbonisation-ammonia-can be obtained only in comparatively small quantity by low temperature carbonisation, and the tars are much less valuable by current standards than those produced at higher temperatures because they lack aromatic constituents and are deficient in some other respects.

Sir George Beilby, who signs this report, has approached the investigation in an entirely sympathetic spirit. As a matter of fact, he was busy with the subject before it excited the amount of interest which is now bestowed upon it, and in this report he has detailed not only the results of experiments carried out by the Fuel Research Board, but reviewed the work of other investigators.

In a preliminary review of the situation, Sir George Beilby points out that broadly speaking this country. 
has to depend on overseas sources for its supply of fuel oil of all kinds, but that the market for fuel oils is not trustworthy commercially, the price having fallen from more than ${ }^{5} l$. per ton to from $3 l .-4 l$. during the past eighteen months. "The bearing of this fall in price upon schemes for the low temperature carbonisation of coal will be at once appreciated when it is stated that it represented a drop of at least ros. on the value of the fuel oil obtainable by carbonisation from $x$ ton of coal." At the same time, it must be remembered that in low temperature carbonisation, fuel oils and gas only amount to about 6 to 9 per cent. respectively of the products, 70 per cent. being coke, and the opinion is expressed that the profitable working of the low temperature process must depend largely upon a recognition of the superiority of low temperature coke to raw coal as a fuel, which takes the practical form of willingness to pay a higher price for it. If that were secured so that the process could be adopted by gasworks, it is suggested that the rich gas produced in the process could be brought into use as an enriching agent for the raising of low grade gas made in other ways to a higher standard of calorific value. Plainly, however, any wide adoption of the process would depend upon the difference in price between the solid smokeless fuel and raw coal being small, and the position is summarised thus: "This process as an industrial operation will stand or fall on a perfectly definite issue which is whether or not it is possible to evolve an apparatus on sound engineering lines in which the capital and working costs would fall within the modest margin of working profit on which the industry must be founded."

The working out of any such process in its best form depends upon a thorough knowledge of the changes which coal, or rather coals, of different kinds undergo in the process of carbonisation, and the report deals with work on this subject. It includes interesting results which have been obtained in a study of the microstructure of cokes produced from different coals in different ways, and emphasises the value which attaches to the proper blending of coals for the carbonisation process as influencing their behaviour in the carbonisation process, and the quality of coke which can be produced from them. The work has, however, gone beyond the laboratory stage, and experimental apparatus has been devised and worked in which the peculiarities of the low temperature process for good or evil have been brought out. The following results can be taken as typical of those obtained by low temperature carbonisation in horizontal retorts:

YIELDS AT $600^{\circ} \mathrm{C}$. PER TON OF COAL (DRY)

Coke . . . . 14.5 to $15.5 \mathrm{cwts}$.

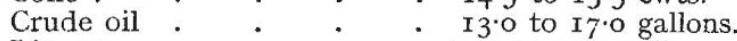
Liquor . . $\quad 7^{\circ} \mathrm{O}$ to $15^{\circ} \mathrm{O}$ gallons. Ammonium sulphate . $\quad 4.5$ to 8.5 lbs. Gas . . . 3000 to $3500 \mathrm{cub}$. ft. $=27$ to 35 therms.

The coke is a smokeless solid fuel, the smokeyielding constituents having been expelled. The gas is in small quantity but rich. The ammonia yield is very small, about one-quarter of what is usual in gasworks practice. The crude oil is some 50 per cent., greater in volume than would occur in ordinary gasworks practice. Its flash point was atmospheric, and when the light spirit was removed from it so as to give a fairly satisfactory flash point the oil was sufficiently fluid to meet the Admiralty specification at $\mathrm{I} 5^{\circ} \mathrm{C}$., but at $0^{\circ} \mathrm{C}$. was much too viscous. The crude oil had a limited miscibility in mineral fuel oilsa grave practical shortcoming. The behaviour of the metal retorts used in this carbonisation was satisfactory in the sense that they showed no sign of distortion or depreciation after using for nearly two years, but the behaviour of steel in the moving parts of an automatic carbonising machine which was tried was not equally satisfactory, defects being encountered due to the loss of rigidity which occurs in steel at a temperature of $600^{\circ} \mathrm{C}$. A number of points requiring further investigation have arisen, and the work now in hand includes the development of automatic methods of carbonisation, the study of briquetting as a preliminary to carbonisation, and the development of a practical method of briquetting at or near the fusing point of the coal. It is along some such lines that it is hoped to arrive at some form of process and appliance for low temperature carbonisation which will meet the technical and commercial demands which have to be satisfied if this method of dealing with coal is to find wide application.

\section{Expedition to Chinese Tibet.}

A S already announced, the Percy Sladen Irust Expedition to the Alps of Chinese Tibet, consisting of Prof. J. W. Gregory and his son, Mr. C. J. Gregory, has returned after a successful journey. The primary object of the expedition was the investigation of the geological structure of the mountain regions of China in localities which would throw light on the relations of the mountains of south-western China to those of the Himalaya and south-eastern Asia. The expedition left Bhamo on the Irrawadi in North Burma on May 7, and crossed the frontier hills to the "Treaty Port" of Tengyueh, where the Indian servants were sent back and a Chinese staff and muleteers engaged. Permission was there given by the Chinese magistrate to go to Likiang-fu, the administrative headquarters on the borders of Chinese Tibet. The expedition was allowed to proceed to Likiang-fu by a route across one of the blank areas on the existing map of Yunnan.

At Likiang-fu it was found that orders had been received from the capital of the province that the expedition was not to be allowed to go farther north ; but the magistrate ultimately agreed to its going on if he were relieved of personal responsibility by a letter stating that the expedition was proceeding at its own risk, and in spite of his warning. From
Likiang-fu it travelled through the valleys of the Yangtze-kiang and the Mekong. Work in the upper Salween valley was found to be impossible, as it was reached in a district smitten with famine owing to the excessive rains of the previous autumn. The return journey to the caravan, which had been left to proceed north along the eastern side of the Mekong, was by forced marches on short rations. At Atuntze excursions were made to the higher mountains between the Mekong and the Yangtze-kiang and to the glaciers of Pei-ma-shan. The return route was through Likiang-fu to the city of Tali-fu and thence by the main trade route across Yunnan to the startingpoint at Bhamo.

The geological collections will, it is hoped, be worked out during the winter, and the results of the expedition can now be judged only by the field evidence. It indicates that while the structure of the foundation of the country is due to the Hercynian movements of upper Palæozoic date, the area has been affected by a series of uplifts which, both by direction and date, belong to a continuation of the Himalayan system into south-western China. Various botanical and zoological collections were made, most of which are being examined at the Natural History Museum, London, and the Indian Museum, Calcutta. 